\title{
D-Penicillamine in the Neonatal Period: Past (!), Present (!?) and Future (?!)
}

\author{
Lajos Lakatos*
}

Faculty of Medicine, Department of Pediatrics, University of Debrecen, Hungary

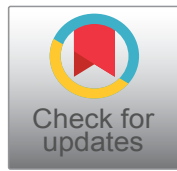

*Corresponding author: Lajos Lakatos, Faculty of Medicine, Department of Pediatrics, University of Debrecen, 4032 Debrecen, Nagyerdei Krt. 1, Hungary, Tel: +36-52-225335, Fax: +36-52-225335

\begin{abstract}
D-penicillamine (D-PA) was first recognized as a potential benefit for neonatal hyperbilirubinemia (NHBI) caused by hemolytic diseases of the newborn infant or immaturity of UDP-glucuronyltransferase enzyme. During a long-term follow up study there was a remarkedly low incidence of retrolental fibroplasia (RLF) in the infants treated with D-PA in their neonatal period. Then, all infants $<1500 \mathrm{~g}$ birthweight were treated with D-PA to prevent retinopathy of prematurity (ROP). This preventive intervention was associated with elimination of all stages of ROP in this randomized, singlecentered comparison analysis (trial or RCT). The 14-day course of D-PA administration were replicated in other institutes in the USA and India. It is important to note that there was no intolerance or short- or long-term toxicity of the medication, in spite of the fact that D-PA was used 1020 times higher doses in the newborn period, than those in adult age. To our concept, the bilirubin-induced neurologic dysfunction (BIND), ROP and Autism Spectrum Disorders (ASD) are neurodegenerative and neurodevelopment diseases (NDs) of immature brain caused by accumulation of free metals and other neurotoxic formations, respectively, in the basal ganglia (BG) and other parts of the central nervous system (CNS) relevant to the above mentioned conditions. The main factor is the hemolysis of neonatal red blood cells. This process is going with the induction of a great amount of heavy metals (mainly iron and copper) and producing reactive oxygen an nitrogen species (ROS and (RNS). These elements are circulating in the bloodstream, and pass through the immature blood-brain-barrier (BBB), finding entrance into the central nervous system (CNS). The author hope that this review will be able to call the attention of neonatologists and the drug manufacturers' onto this promising intravenous drug treatment.
\end{abstract}

\section{Keywords}

D-Penicillamine in the neonatal period, Orphan drug, Copper hypothesis of BIND, ROP and ASD, Follow-up studies

\begin{abstract}
Abbrevations
ASD: Autistism Spectrum Disorders; BG: Basal Ganglia; BIND: Bilirubin-Induced Neurologic Dysfunction; BBB: BloodBrain-Barrier; Bw: Birthweight; CNS: Central Nervous System; Cp: Ceruloplasmin; D-PA: D-Penicillamine; ET: Exchange Transfusion; ET-1: Endothelin-1; HO: Heme Oxygenase; iNOS: Inducible Nitric Oxide Synthase; (IV): Intravenously; MD: Metal Dyshomeostasis; NHBI: Neonatal Hyperbilirubinemia; ND: Neurodegenerative or Neurodevelopmental Disease; OS/ NS: Oxidative/Nitrosative Stress; PO: Per Os (enteral); ROP: Retinopathy of Prematurity; ROS: Reactive Oxygen Species; RNS: Reactive Nitrogen Species; TBS: Total Serum Bilirubin Level; VLBW: Very Low Birth Weight
\end{abstract}

\section{Past}

\section{Introduction}

D-PENICILLAMINE (D-PA) was first isolated as an amine from the degradation products of penicillin by Abraham, et al. in 1942 [1]. Clarke and Cornforth perceived the similarity to the naturally occurring amino acid L-cysteine, and postulated the formulation as $\beta$ - $\beta$-dimethylcysteine [2]. Unlike its precursor penicillin, D-PA does not have any antibiotic activity and so initially, interesting the compound arose only out of its position in the processes of degradation and synthesis of penicillin. Nevertheless, it subsequently has found an extensive use in medicine: firstly in 1956 by Walshe, in the treatment of Wilson's disease [3]. It has since been used or suggested for use in the treatment of cystinuria, Rheumatoid arthritis (RA), juvenile RA, palindromic rheumatism, scleroderma, primary biliary cirrhosis, alcohol detoxification, heavy metal removal, chronic active hepatitis, morphea, keloid, keratosis 
Table 1: History and mode of administration of D-PA in neonates in Debrecen NICU (in NHBI the drug was used $3 \times 100 \mathrm{mg} / \mathrm{kg}$ bw. daily for 1-7 days, IV or PO depending on TSB).

\begin{tabular}{|l|l|l|l|}
\hline & First period (1973-1979) & Second period (1979-1980) & Third/fourth period (1981-1982) \\
\hline $\begin{array}{l}\text { Dosage and } \\
\text { administration }\end{array}$ & $3 \times 100 \mathrm{mg} / \mathrm{kg} \mathrm{bw.}$ & $3 \times 100 \mathrm{mg} / \mathrm{kg} \mathrm{bw}$ & $3 \times 100 \mathrm{mg} / \mathrm{kg} \mathrm{bw}$ \\
\hline $\begin{array}{l}\text { Aim of the IV drug } \\
\text { administration }\end{array}$ & only NHBI & IV for 3 days & IV for 3 days $+50 \mathrm{mg} / \mathrm{kg} \mathrm{IV} \mathrm{for} 2$ weeks \\
\hline
\end{tabular}

follicularis, and hyperviscosity syndrome et cet. In addition, it has been used as a ligand in the preparation of radiopharmaceuticals for liver and kidney imaging [4]. Only D-PA is used in medicine, since the L-isomer and the DL-isomer (or racemate) are toxic.

\section{D-PA in the neonatal period}

In this survey I will review our D-PA research, which embraces a period of more than 45 years and intending to focus on a few aspects which seems to me as especially important for neonatologists and pediatricians. When in the early 1970s, we reviewed the role of D-PA in the treatment of neonatal hyperbilirubinemia (NHBI) the drug was new to most neonatologists $[5,6]$. The idea that D-PA might be a suitable drug to act as a copperbinding agent for use to control icterus neonatorum occurred, serendipituously, to me, while reflecting on the similarity of copper storage in Wilson's disease and neonates. It is well known that all neonates have increased concentration of copper in their liver and brain, and a decreased concentration of a specific plasma copper-protein, ceruloplasmine (Cp), in comparison with individuals over one-year-old [7]. D-PA has been found effective to decrease the concentration of bilirubin in blood samples in vitro. Subsequent clinical studies for control of NHBI was introduced to our department in March 1973. This drug, given intravenously (IV) to newborns, greatly reduces the TSB or prevents its increase, which is usually seen during the first few days of life. This treatment is especially effective in jaundice of hemolytic origin, such as ABO- or Rhesus incompatibility, and used together with phototherapy it has largely replaced exchange transfusions (ETs) in several neonatal units in Hungary and other countries [8-14].

In the course of conducting clinical trials to investigate the presumably beneficial effects of D-PA in the reduction of retinopathy of prematurity (ROP) $[15,16]$ we routinely measured the TSB of very low birth weight (VLBW) infants. There was no significant difference between the D-PA-treated and control groups either in the mean peak TSB or in the number of ETs needed. This suggests phototherapy alone proved to be just as effective as phototherapy plus D-PA in babies with a birth weight under $1500 \mathrm{~g}$. The most frequent clinical factors in the severity of NHBI of VLBW infants include increasing immaturity, unrecognized neonatal hemolysis, array of genetic conditions or concurrent conditions of dehydration, sepsis or acidosis, hypoalbuminemia and/or poor feeding (Table 1).

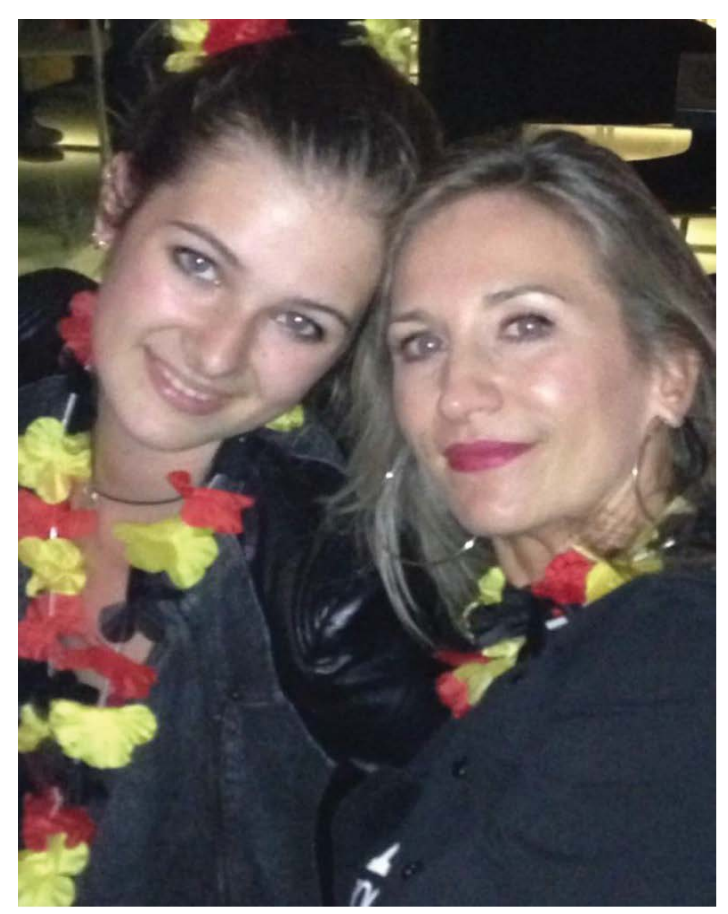

Figure 1: The first patient with her daughter of eighteen (with permission).

\section{Case report}

There were some very impressive cases in our practise in neonatology deserved to show them individually. The first patient who were treated with D-PA in her neonatal period was an ABO-incompatible preterm infant with birthweight of $2200 \mathrm{~g}$. At an extremely high TSB $(32.5 \mathrm{mg} / \mathrm{dL}=546 \mathrm{micromol} / \mathrm{L})$ IV administration was begun. The first dose caused a spectacular fall of $6.5 \mathrm{mg} / \mathrm{dL}$ in TSB within 4 hours, and under the influence of such treatment, we were able to witness a gradual disappearance of the NHBI. She is now a member of a famous operhouse in Germany as an opera singer (Figure 1) [17]. This case is all the more remarcable because the baby showed typical symptoms of acute bilirubin encephalopathy at 3-6 days of age: Somnolence, hypotonia, loss of the Moro reflex and sometimes opisthotonus. In addition, she was in need of cardiopulmonary resuscitation (CPR) just at the beginning of the ET because of a cardiac arrest, so, the intervention (ET) was not performed and it proved to be unsuccessful concerning the high TSB. Surviving the neonatal period, however, she have not been demonstrated any chronic manifestations of BilirubinInduced Neurologic Dysfunction (BIND), including the most common sequelae of sensorineural hearing imperment. The lack of chronic (residual) symptomes 


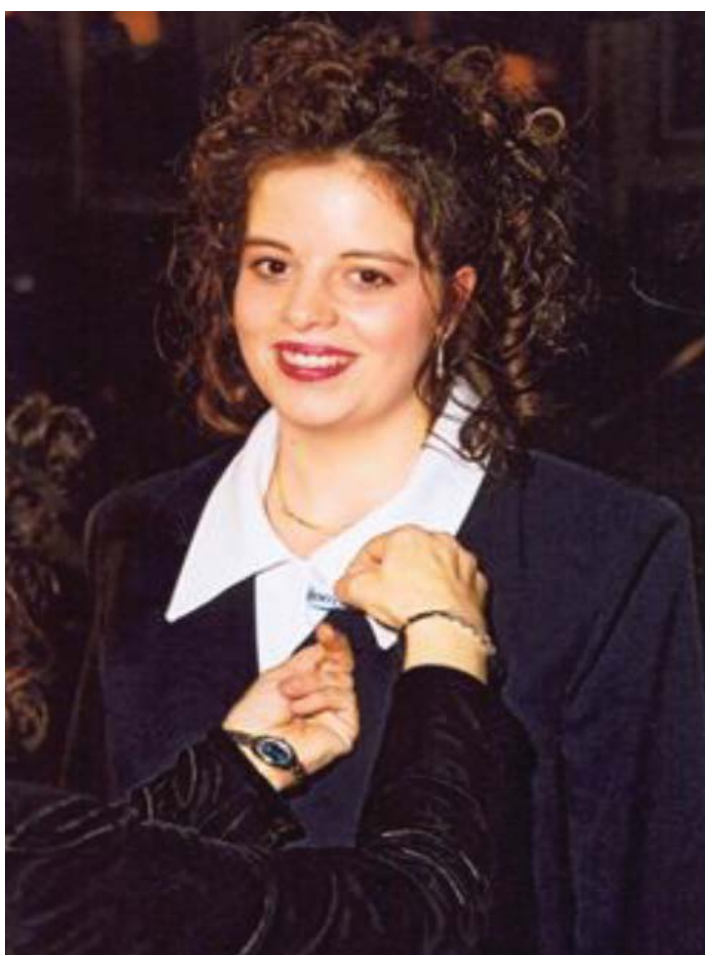

Figure 2: This attractive girl in her graduation ceremony was born under $800 \mathrm{~g}$ birth weight. Now she doesn't wear glasses or contact lens (with permission).

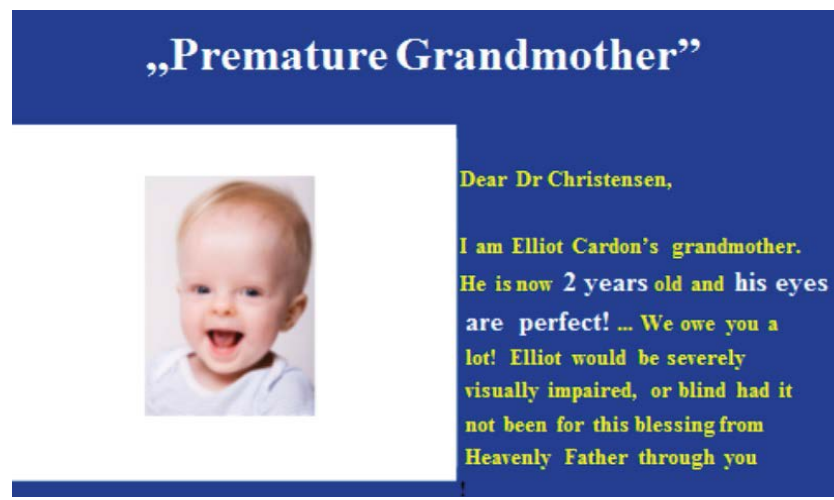

Figure 3: Grandchild's photograph and Grandma's grateful letter to (http://elliotspreemietees.blogspot.com/).

is - with great probability - due to the neuroprotective effects of D-PA in the neonatal period (see: below Present).

\section{Prevention of ROP}

In industrialized countries, ROP has been characterised by two notable epidemics over the past 75 years. The first epidemic ceased following controlled oxygen administration. The second epidemic of ROP has occured due to increased survival rates of VLBW infants. A current concern is that a third epidemic of ROP may be emerging: ROP now becoming more significant in developing countries as well, in addition not only in so called "fetal infants" with around $500 \mathrm{~g}$ birth weight, but above or equal to $1000 \mathrm{~g}$ [18].

The history of D-PA therapy in neonates under $1500 \mathrm{~g}$ birth weight can be divided into four periods. During the first period D-PA was used only against

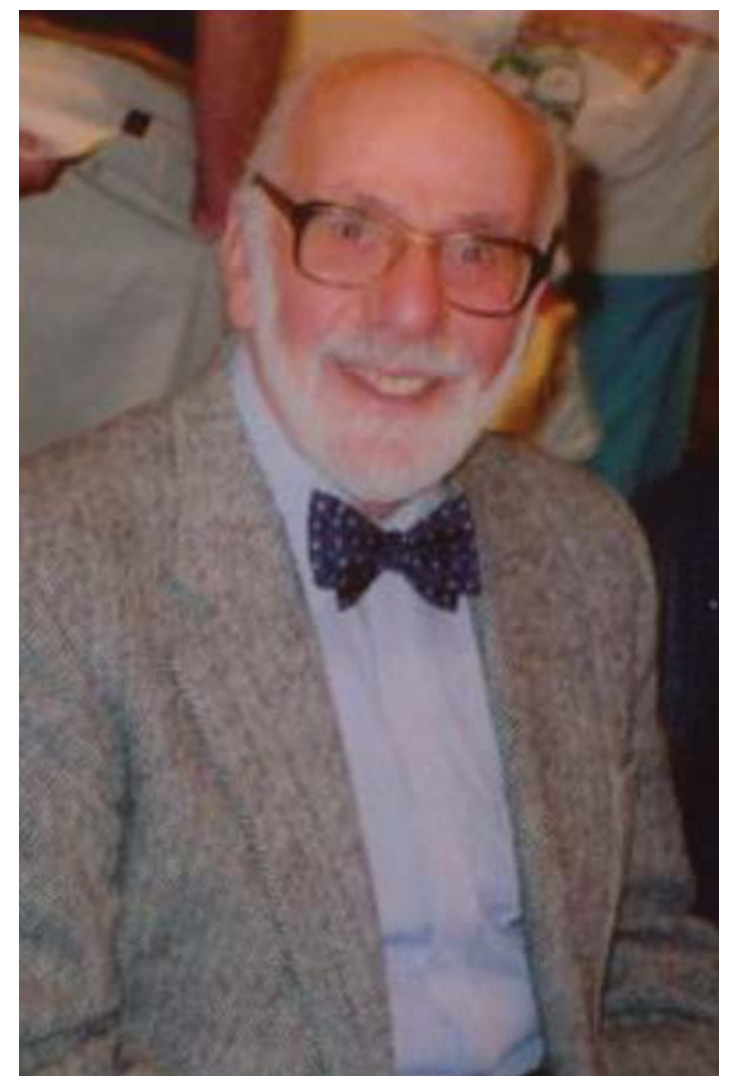

Figure 4: Professor William A Silverman 1917-2004.

neonatal jaundice. The original aim of our retrospective screening program, carried out in 1979, was to estimate the incidence of retrolental fibroplasia (RLF) [19]. It was surprising that among D-PA recepient babies $(n=62)$ there was only one case of RLF, whereas ten out of the 132 without such treatment developed severe cicatricial stages of the disease [20]. We then decided that all infants weighing $<1500 \mathrm{~g}$ birthweight and requiring supplemental oxygen should receive D-PA therapy. During the second period there was one case out of 133 infant survivals where RLF developed. This baby received three days treatment and three weeks oxygen therapy. We then changed the dosage and duration of D-PA administration. During the third period the new mode of the drug administration, however, was still not able to totally eradicate the occurence of RLF. During the fourth period we conducted a strictly controlled prospective trial to investigate the presumably beneficial effects of D-PA not only in the prevention of the cicatricial form of the disease but also in the reduction of the acute stages of retinopathy $[15,16]$. During the 22-month study period nine infants were diagnosed as having ROP stage I or greater during their hospital stay. These premature infants belonged to the control group, so that, with respect to the frequency of active phases, the difference between the D-PA-treated and control group is statistically significant [21-25].

Finally, we show here two photos of a Hungarian girl (Figure 2) and an American boy (Figure 3). They were born under $800 \mathrm{~g}$ birthweight, received long-term oxygen therapy and a short-term D-PA treatment. 


\section{Non-replication of the replicable}

Dr. William A. Silverman has written the above quoted title. He was "the pope of neonatology", the author of famed books and proved to be our greatest mentor and supporter [26-29]. Bill has reviewed our reseach work in details, and insisted on the importance of replications (Figure 4).

I can say that until Silverman's declaration only sporodical publications appeared in Hungarian and Polish journals $[8,10-14]$ mainly about the treatment of neonatal jaundice. Then, we published a provocative letter [30] to persuade others to perform randomized controlled trials in the prevention of ROP. This letter and a personal meeting resulted in publications from Christensen and his coworkers [31,32] which can be considered as the first international replication of our observation and clinical trials. They also recognised no immediate intolerance of the prepared solution of D-PA given by nasogastric tube, nor did they observe any evidence of renal, haematological, or hepatic toxicity in patients approved by the Food and Drug Administration (FDA).

Although the UTAH-study was performed in a subsequent century, its results confirmed our findings of controlled trials, namely no babies had ROP with birth weight above $750 \mathrm{~g}$ (in Hungary) or $650 \mathrm{~g}$ (in Utah, US), respectively, and no adverse effects were observed. Consequently we agree with the conclusion, and that further multicentered, randomized, placebo-controlled clinical trials are warranted. It seems to us that D-PA does indeed reduce the retinal revascularization, but not sufficient to prevent the cases occuring among babies with average birthweight around $600 \mathrm{~g}$.

Later, a research group in India conducted a prospective controlled trial $[33,34]$ without any reduction in the number of ROP in the D-PA-treated group. This controversal outcome was reflected in the Cochrane rewiews concerning the prevention of ROP $[25,34]$. The explanation of difference lies (1) In the mode of administration of D-PA (parenteral- or oraltreatment) and (2) In the start of treatment (within 12 hours or 3-5 days of age). At the same time the drug was well tolerated and did not have any major short-term adverse effects. In conclusion, the Indian authors have written the followig sentences: ".....in our study, the mean age of administration in the D-PA group was 3.5 \pm 1.91 days,....this was because enteral administration in our study was possible only after establishing feed tolerance,.... The bioavailability of enteral D-PA may be poorer than intrvenous $D-P A, \ldots . . .$. retinal angiogenesis happens to commences very early in the neonatal period".

We may accept the latter statements without debate [35].

\section{Present}

\section{Administration only enterally}

Bizarrely, D-PA is a very cheap, low-cost drug, but at the same time it is developed under the Orphan Drug Act of 1983 in the U.S. which is a federal law concerning rare diseases (orphan diseses) [36]. This means that the pharmaceutical companies produce this "homeless, not a money-maker" drug with reluctance. For example the IV form of D-PA is nowdays not available in the market and the per os preparation is produced by a few companies in the world. The bioavailability of intravenously administered drug is $100 \%$ since no absorption process is involved. The rate of absorption of orally administered drugs is slower in neonates and young infants due to delayed gastric emptying resulting to prolongation in time required to achieve maximal plasma concentration. In the early period of D-PA therapy we used lower doses and, observing the lack of any adverse effects, we raised the dose gradually until the achievement of optimal bilirubin decrease. Compared with later age, neonates have significant differences in physiology affecting drug absorption, distribution, metabolism, and elimination. Fortunately, the developmental pharmacology and the age related effects of D-PA largely favoured by the administration of unusually high dosis of this drug $[37,38]$. Paediatric patients display different pharmacokinetic and pharmacodynamic responses to drugs. This is why we can speak about developmental or age-related pharmacology. In the Table 2 we demonstrate the results of our animal experiments regarding the agerelated differences in the effects of D-PA [17]. The high activity of $\mathrm{HO}$ in the newborn could reflect the enzymeinducing action of metals - maily $\mathrm{Cu}$ and $\mathrm{Fe}$ - derived from the breakdown of fetal erythrocytes [39].

Since the IV administration is not possible nowdays, according to the already mentioned American and Indian authors, likeweise our present praxis, the enteral

Table 2: The age-related differences in effects of D-PA.

\begin{tabular}{|c|c|c|}
\hline & Neonates & Adults \\
\hline Hexobarbital sleeping-time & shortened & no effect \\
\hline Heme oxygenase-1 & inhibited & no effect \\
\hline Cytochrom- P-450 & increased & no effect \\
\hline Catalase & increased & no effect \\
\hline Peroxidases & increased & no effect \\
\hline LD50 & $>4000$ mg/kg (IP) & 500 mg/kg (IV) \\
\hline Radioprotection & significant & $?$ \\
\hline
\end{tabular}


administration also a promising treatment especially in $\mathrm{NHBI}$, and less effective in prevention of ROP $[12,13,31,33,40-42]$.

\section{Future}

D-PA can exert neuroprotective effects in BIND, ROP, ASD and may be in other neurodegenerative disorders. Our observations - together with other convincing cases participating in the long-term (28-40 years) follow-up - suggest that DPA-therapy in the neonatal period may have significant neuroprotective effects in cases jeopardized by BIND, ROP and may be ASD or other neurodegenerative diseases [17]. According to our hypothesis D-PA can modulate the function of gasotransmitters and alters the copper homeostasis in the brain, so, it can protect the brain (especially the basal ganglia and retina) from various injury. During the last 45 years Hungarian neonatologists have treated a number of term- and preterm- infants with D-PA. No acute or long-term adverse effects or any late complications of this treatment protocol have been observed during several years of follow-up. According to our opinion, the most important "discovery" of D-PAproject is that this drug should be undoubtedly effective (jaundice, ROP, lead burden [43] and may be effective in the prevention of ASD (a well-designed, large multicenter randomized controlled trial is required) and the HIV's vertical infection [44]. It is safe (more than 2530000 cases only in Hungary without any side effects!) and quite inexpensive (even more for the developing countries!), and it can be used in unusually high doses as a short-term therapy in the neonatal brain's defence [45-51].

Finally, despite many decades of interest and repeated claims about the causal role of various factors in the pathogenesis of BIND, ROP and ASD, and their prevention or therapy, the matter remains completely unsettled. In 1985, encouraging initial results of D-PA prevention in ROP were confirmed in CRTs. Once more, no effort has been made to organise an international independent multicentre prospective controlled clinical trial yet, and the uncertainty about the use of this approach remains unresolved.

\section{Proposal for international controlled trial}

Title: Will D-penicillamine administration (if possible intravenous administration) reduce the incidence of ROP or ASD among very low birthweight preterm babies or infants with birthweight $>2000 \mathrm{~g}$ with hyperbilirubinemia? The first dosis must be administer within 12 hours of life.

This would be a prospective, randomized, placebocontrolled, multicentered trial, and a 5 years project.

\section{Ethical Approval}

This study was approved by the local ethics committee. Written informed consent was obtained from all the parents.

\section{Financial Support}

Not needed.

\section{Conflict of Interest}

None declared.

\section{References}

1. Abraham EP, Chain E, Baker W, Robinson R (1943) Penicillamine, a characteristic degradation product of penicillin. Nature 151: 107.

2. Clarke HT (1949) The chemistry of penicillin. Princeton University Press.

3. Walshe JM (1956) Penicillamine, a new oral therapy for Wilson's disease. Am J Med 21: 487-495.

4. Howard-Lock HE, Lock CJL, Mewa A, Kean WF (1986) D-penicillamine: Chemistry and clinical use in rheumatic disease. Semin Arthritis Rheum 15: 261-281.

5. Lakatos L, Kövér B (1974) Az újszülöttkori hyperbilirubinaemiák D-Penicillamin therapiája. Orv Hetil Hungarian J Med 115: 307-311.

6. Lakatos L, Kövér B, Péter F (1974) D-Penicillamine Therapy of Neonatal Hyperbilirubinaemia. Acta Paediatr Acad Sci Hung 15: 77-85.

7. Olivares M, Araya M, Uauy R (2000) Copper homeostasis in infant nutrition: Deficit and excess. J Pediatr Gastroenter Nutr 31: 102-111.

8. Korányi G, Kovács J, Vörös I (1978) D-Penicillamine treatment of hyperbilirubinemias of preterm infants. Acta Paediatr Acad Sci Hung 19: 9-16.

9. Nagy A, Felszeghi E (2000) Successful combined treatment of orally administered D-penicillamine and phototherapy for Rh-Hemolytic Disease of a newborn. Gyermekgyógyászat 51: 81-83.

10. Dolinay T, Szombathy G (1974) D-Penicillamin felhasználása az újszülöttkori hyperbilirubinaemiák terápiájában. Orv Hetil 115: $1431-1432$.

11. Szűts A, Lechner E (1999) ABO haemolytikus betegség konzervatív kezelése. Gyermekgyógyászat 50: 67-69.

12. Rokicki W (1989) D-Penicylamina-nowy lek w profilaktyce I terapii noworodka? Polish-Przeg Ped 19: 229-233.

13. Valenzuela CA (2008) Personal communication in Mexico during a lecture-tour.

14. Lakatos L, Ohls RK (2003) Step Before the „First Step”. Transf Alternat in Transf Med (TATM) 4: 226-228.

15. Lakatos L, Hatvani I, Oroszlán G, Vekerdy Z, Kincses E, et al. (1986) Controlled trial of D-Penicillamine to prevent retinopathy of prematurity. Acta Paediatr Hung 27: 47-56.

16. Lakatos L, Lakatos Z, Hatvani I, Oroszlan G (1987) Controlled trial of use of d-penicillamine to prevent retinopathy of prematurity in very low- birth-weight infants. In: Care Stern L, Oh W, Friis-Hansen B, Physiologic foundations of perinatal. Elsevier 2: 9-24.

17. Lakatos L, Balla G (2016) D-Penicillamine in the neonatal period: Chelation as neuroprotectant in the neonatal period. LAMPERT Academic Publishing, 42.

18. Phelps DL (1992) Retinopathy of prematurity. Current Problems in Pediatrics 22: 349-371. 
19. Wheatley CM, Dickinson JL, Mackey DA, Craig JE, Sale MM (2002) Retinopathy of prematurity: recent advances in our understanding. Br J Ophthalmol 86: 696-700.

20. Lakatos L, Hatvani I, Karmazsin L, Oroszlan G, Vekerdy Z (1980) A koraszülöttek D-Penicillamin kezelése csökkenti a retrolentális fibroplasia gyakorisáságát? Szemészet J Hungarian Ophthalmology 117: 9-12.

21. Lakatos L, Hatvani I, Oroszlán G, Karmazsin L, Vekerdy Z (1985) Clinical observations in the prevention of retrolental fibroplasia with D-Penicillamine. In: Stern L, Xanthou M, Friis-Hansen, Praeger B, Physiologic Foundations of Perinatal Care. 1: 293-304.

22. Flinn JT (1984) An international classification of retinopathy of prematurity: Clinical experience. Trans Am Ophthalmol Soc 82: 218-238.

23. Lakatos L (1984) D-Penicillamin in der Prophylaxe der Retinopathie praematurorum. In: Körner F, Bossi E, Die Retinopathiedes Frühgeborenen. Gustav Fischer Verlag, 197-199.

24. Lakatos L, Hatvani I, Oroszlán G, Karmazsin L, Vekerdy Z (1985) A koraszülöttek retinopathiájának megelôzése D-Penicillaminnal. Orv Hetil 126: 1391-1396.

25. Phelps DL, Lakatos L, Watts JL (2001) D-Penicillamine for preventing retinopathy of Prematurity. Cochrane Database Syst Rev CD001073.

26. Silverman WA (1980) Retrolental fibroplasia: A modern parable. Elsevier Health Sciences, Imprint Grune \& Stratton Inc.

27. Silverman WA (1998) Where's the evidence? Debates in modern medicine. Oxford University Press 163-166.

28. Chalmers I (2005) In memoriam Bill Silverman: A personal appreciation. Paed Perinat Epidem 19: 82-853.

29. Lakatos L (2005) In Memoriam William Aaron Silverman (1917-2004). Orv Hetil 146: 1497-1499.

30. Lakatos L, Phelps DL, Watts J (1999) International replications, anyone? Arch Dis Child Fetal Neonatal Ed 80: 252.

31. Christensen RD, Alder SC, Richards SC, Richards $M$, Lambert DK, et al. (2006) A pilot trial testing the feasibility of administering D-Penicillamine to extremely low birthweight neonates. J Perinatol 26: 120-124.

32. Christensen RD, Alder SC, Richards SC, Horn JT, Lambert DK, et al. (2007) D-Penicillamine administration and the incidence of retinopathy of prematurity. J Perinatol 27: 103111.

33. Tandon M, Dutta S, Dogra MR, Gupta A (2010) Oral D-penicillamine for the prevention invery low birth weight infants: a randomized, placebo-controlled trial. Acta Paediatr 99: 1324-1328.
34. Qureshi MJ, Kumar M (2013) D-Penicillamine for preventing retinopathy of prematurity in preterm infants. Cochrane Database of Systematic Reviews CD001073.

35. Beharry KD, Valencia GB, Lazarro DR, Aranda JV (2016) Pharmacologic interventions for the prevention and treatment of retinopathy of prematurity. Semin Perinatol 40: 189-202.

36. Orphan drug.

37. Lakatos L, Oroszlán G, Dézsi Z, Hatvani I, Karmazsin L (1982) Age-related difference in radioprotective effect of D-Penicillamine. Dev Pharmacol Ther 5: 120-126.

38. Ku LC, Smith PB (2015) Dosing in neonates: Special considerations in physiology and trial design. Pediat Res 77: 2-9.

39. Maines MD, Kappas A (1977) Metals as regulators of heme metabolism. Science 198: 1215-1221.

40. Lakatos L, Csáthy L, Nemes É (1999) "Bloodless" treatment of a Jehovah's witness infant with AB0 hemolytic disease. $J$ Perinatol 19: 530-532.

41. Nagy A, Lakatos L (2005) D-penicillamine treatment in RhHaemolytic Disease of a newborn. Arch Dis Child.

42. Lakatos L (2004) Bloodless treatment of infants with haemolytic disease. Arch Dis Childh 89: 1076.

43. Lakatos L (1993) Mythology of lead poisoning. Pediatrics 91: 160.

44. Lakatos $L$ (2013) D-penicillamine in the neonatal period: A cost-effective approach to HIV-positivity due to vertical transmission. Internat J Educat Develop 2: 225-227.

45. Lakatos L, Balla G, Pataki I (2016) New concept of bilirubininduced neurologic dysfunction: Neonatal brain insults of metal (copper) dyshomeostasis. EC Paediatrics 3: 281-288.

46. Lakatos L, Balla G (2016) From the image towards a new concept. Metab Brain Dis 31: 485-486.

47. Lakatos L, Balla G, Pataki I (2017) Metal mediated bilirubin encephalopathy: Treatment with D-Penicillamine. J Pediatr Neonatal Biol 1: 1-4.

48. Lakatos L, Balla G (2017) Bilirubin-induced neurologic dysfunction (BIND): Appearances are fairly often deceptive. Birth Defects (BDJ) 1: 1-4.

49. Lakatos L, Pataki I, Balla G, Vekerdy-Nagy Z (2017) Penicillamine - preventing or "curing" autism spectrum disorders in the neonatal period? EC Paediatrics 6: 51-52.

50. Lakatos L, Balla G, Pataki I, Vekerdy-Nagy Z (2017) Penicillamine: From the BIND, through the ROP, till the ASD in the neonatal period. EC Neurology 01: 14-17.

51. Lakatos L (2018) Early diagnosis and prevention of hyperbilirubinemia and autism spectrum disorder. Clin Res in Pediatr 1: 1-2. 